Research Article

\title{
Effect of deficit irrigation and kaolin clay on yield and yield components of pumpkin (Cucurbita pepo L.)
}

\author{
Mikaiel Khalili ${ }^{1}$ Fatemeh Nejatzadeh ${ }^{1,2}$
}

Received: 26 November 2020 / Accepted: 24 March 2021

Published online: 14 April 2021

(c) The Author(s) 2021 OPEN

\begin{abstract}
This experiment was conducted to determine the effect of kaolin clay application and deficit irrigation on quantitative characteristics of pumpkin in a field located in Siahbaz village of Khoy, Iran. In order to investigate the effect of irrigation and kaolin clay on yield and yield components of (Cucurbita pepo L.), this experimental was considered. An experiment was performed with irrigation at four levels (complete irrigation, deficit irrigation from the shoot stage, deficit irrigation from flowering stage and deficit irrigation from seed filling stage) and three levels of kaolin foliar application (control, $3 \%$ kaolin and $6 \%$ kaolin) was considered. Analysis of variance showed that deficit irrigation and kaolin had significant effect on number of seeds per fruit, fruit yield, 1000 grain weight, grain and biological yield, harvest index, oil and protein percentage, oil yield and protein yield. Maximum grain weight ( $294.5 \mathrm{gr})$, grain yield $\left(807 \mathrm{~kg} \mathrm{ha}^{-1}\right)$, oil percentage (46.2) and oil yield $\left(373.3 \mathrm{~kg} \mathrm{ha}^{-1}\right)$ were related to complete irrigation treatment. The highest grain weight (257.07 gr), grain yield $\left(733 \mathrm{~kg} \mathrm{ha}^{-1}\right)$ and fruit yield $\left(23.8 \mathrm{~kg} \mathrm{ha}^{-1}\right)$ were observed in the $3 \%$ kaolin. Based on the results, deficit irrigation at seed filling stage was superior to other treatments. Kaolin had no effect on grain yield and could be interrupted once without irrigation. Kaolin used in this experiment under irrigation limitation conditions could partially offset the waterdeficit yield due to control treatment. Due to lack of water, yield of untreated plants was lower than kaolin-treated ones.
\end{abstract}

Keywords Transpiration · Grain yield · Irrigation cut · Kaolin · Pumpkin seed

\section{Introduction}

One of the most important and valuable plants in the pharmaceutical industry is the (Cucurbita pepo L. var. syriaca), [30] which belongs to the Cucurbitaceae family and has recently entered the Iranian plant community [37]. Pumpkin is a one-year-old herbaceous plant with creeping and fluffy stems, with male and female flowers on a single rootstock [5]. Flowers are yellow and five loops. Female flowers are shorter than male flowers [29]. Fruits are fleshy, coarse or spherical more and less elongated. The shape of the fruit is related to species. Ripe fruits are yellow or greenish yellow. Inside each fruit, there are 400-500 seeds. The color of the seed is dark green or olive green. Seed length is $15 \mathrm{~mm}$, width of $8-10 \mathrm{~mm}$ and thickness of $2.5-3 \mathrm{~mm}$. Surrounding the grain is a transparent, delicate coating. The weight of a 1000 grains is $200-300 \mathrm{~g}$. Seeds contain 40-60 percent oil. The most important fatty acid constituting the oil is linoleic acid (45-50\%). The oil also contains valuable substances such as vitamin $\mathrm{E}$ (more than $30 \mathrm{mg}$ per $\mathrm{kg}$ ), phytosterol and protochlorophyll [7]. The scarcity of resources on the one hand and the increase in population on the other hand make the need for more efficient use of water to increase performance inevitable. Since agriculture is the major consumer of water, any savings in this sector will be considered as

Fatemeh Nejatzadeh, fnejatzadeh@yahoo.com | ${ }^{1}$ Physiology of Medicinal, Spice and Aroma Medicines, Khoy Branch, Islamic Azad University, Khoy, Iran. ${ }^{2}$ Department of Horticulture, Khoy Branch, Islamic Azad University, Khoy, Iran. 
an effective contribution to saving water resources. The role of water in plant physiology is crucial because of its vital role in all physiological processes as well as the high quantity needed for the plant [24]. Irrigation is carried out to maintain the soil moisture in an optimum condition and to minimize stress to the crop during the growing season [26]. Therefore, in the rainy season, the efficiency of the water used for irrigation should be seriously considered when planning irrigation. Iran is classified as arid and semiarid regions of the world with average rainfall of $240 \mathrm{~mm}$, and drought stress is inevitable in crop growth period [22]. In general, successful crop production in areas with frequent droughts requires methods and practices to provide or maintain sufficient plant moisture. Some of these methods include: selecting early or dehydrated plants, using cultivation techniques and applying technologies that increase the amount of water stored in the soil or reduce the amount of water consumed due to the limited amount of water available. Use of methods such as change in cropping pattern and replacing plants with less water requirement instead of plants with high water demand, mulching, changes in crop management such as conservative tillage or regulated deficit irrigation, fertilizer type, irrigation type and application of transpirants at small-scale levels together can make a big leap against drought and reduce the amount of evapotranspiration [20]. In recent years, anti-transpiration materials have been considered as a method to reduce water loss from plant leaves by reducing the size or number of stomata, thus reducing the rate of water vapor. Anti-transpirant may serve to increase albedo, to reduce leaf heating and therefore consequently reduce transpiration [11]. Of course, the penetration of carbon dioxide into the stomata of leaf is necessary for photosynthesis, and if the stomata cell was closed, the yield of photosynthesis was reduced. Spraying canopies of plants with suspension of particles of clay as an antiperspirant materials has long been used to limit of losing of water and heat stress on crops. The experiment by Fumiomi Takeda [10] showed that 4-cm hydrophobic kaolin mulch applied after planting can suppress weeds without affecting blackberry productivity [10]. A reflective Kaolin spray was found to decrease leaf temperature by increasing leaf reflectance and to reduce transpiration rate more than photosynthesis in many plant species grown at high solar radiation levels. Early studies demonstrated that the reflective Kaolin improved water status and yield of water-stressed apple seedlings, while it did not reduce carbon assimilation [13]. Foliar application of kaolin has been evaluated for its ability to reduce the negative effects of water stress and to improve the physiology and productivity of plants [33]. The use of kaolin has been found to improve the photosynthetic rate under water deficit conditions by increasing photosynthesis levels in olive plants
(Olea europaea L.) [8], enhancing the leaf water potential of tuberose plants (Polianthes tuberosa L.) [28] and grape plants (Vitis vinifera L.) [15] and increasing the water use efficiency in grapefruit leaves by $25 \%$ [19]. Deficit irrigation will play an important role in farm-level water management strategies, with consequent increases in the output generated per unit of water used in agriculture. In Iran, it is necessary to produce the maximum yield and profit from a unit area by using available water efficiently because the existing agricultural land and irrigation water are rapidly diminishing. Therefore, it is essential to balance water requirements, water consumption and yield of summer squash. Youssef et al. [39] reported decreasing water levels caused a significant reduction in the all tested growth and yield parameters, i.e., canopy weight, root weight, number of leaves, leaves fresh weight and leaf area as well as photosynthetic pigments content (total chl. and carotenoids), total yield, fruit weight and length. While increasing ascorbic acid spraying foliar application levels as antioxidant significantly increased the aforementioned parameters in the two seasons as compared with control. On the other hand, decreasing water levels caused a significant increasing in leaf proline content, leaf cell sap osmotic pressure, dry matter \% and fruit TSS in the two growing seasons as compared with control.

Hamzei and Babaei [17] investigated the effects irrigation interval and different levels of nitrogen fertilizer on some of morphological traits, yield components and seed yield of Cucurbita pepo. Their results showed that the effects of treatments were significant on plant length, nod and branch number/main stem, leaf and fruit number/ plant, seed number/fruit, 100-seed weight, grain yield and chlorophyll index of pumpkin. Also, interaction of treatments had significant effect on all traits except branch number/main stem and seed number/fruit. The highest and lowest grain yield was 84.84 and $25.26 \mathrm{~g} \mathrm{~m}^{-2}$, which achieved at $180 \mathrm{~kg} \mathrm{~N}$ in 6 days irrigation interval and non-supplying $\mathrm{N}$ in 15 days irrigation interval treatments, respectively. Treatment of $180 \mathrm{~kg} \mathrm{~N}$ in 6 days irrigation interval did not differ with treatment of $180 \mathrm{~kg} \mathrm{~N}$ in 9 days irrigation interval. Drought stress occurrence and nutrient deficiency, especially nitrogen during development stages especially reproductive stages, caused decrease in yield components and eventually seed yield through reduction in chlorophyll content; reduction in photosynthesis period and material translocation resulted from current photosynthesis and also reduction of proportion of supplied remobilization of materials. Generally, results of this experiment showed that the highest grain yield was obtained in the treatment of irrigation interval of 6 days with accompanying consumption of $180 \mathrm{~kg} \mathrm{~N}$, but there was no significant difference between the mentioned treatment and the treatment of 9 days irrigation interval and $180 \mathrm{~kg} \mathrm{~N}$. 
So, it can be concluded that irrigation interval of 9 days and application of $180 \mathrm{~kg} \mathrm{~N} \mathrm{ha}^{-1}$ can produce satisfactory yield besides water saving and reduction in production cost particularly for using less nitrogen fertilizers.

Ibrahim and Selim [18] investigated the effect of irrigation intervals and anti-transpirant (kaolin) on summer squash (Cucurbita pepo L.) growth, yield, quality and economics. Their results show that with increasing irrigation intervals from 8 up to 16 days caused significant increases in leaves dry matter percentage, total soluble solids and dry matter percentage in fruit and water use efficiency. The interaction effect between irrigation intervals and kaolin levels was significant for all the studied parameters. The highest net return was observed with plants watered every 8 days and received kaolin at $6 \%$ concentration followed by watered every 12 days and received kaolin at $6 \%$ concentration that had higher benefit/cost ratio. From the economic and nutritional point of view, it could be concluded that irrigation every 12 days intervals combined with spraying kaolin at $6 \%$ concentration to summer squash cv. Eskandrani might give the chance for increasing water use efficiency and produce satisfactory and good marketable fruit yield under similar conditions of this work.

Habibi et al. [16] investigated the effects of biochemical and organic fertilizers on yield and seeds NPK contents of pumpkin (Cucurbita pepo var. styriaca). Their results show that the maximum seed yield was obtained from the treatment that pumpkin seeds inoculated with free-living $\mathrm{N}$ (NFB) and phosphate-solubilizing bacteria (PSB) $+50 \%$ organic fertilizer. The highest fruit yield was obtained from $\mathrm{NFB}+\mathrm{PSB}+50 \% \mathrm{C}+50 \% \mathrm{O}$. It was concluded that application of biofertilizers in combination with $50 \%$ chemical and organic fertilizers reduced the use of chemical fertilizers and produced higher seed and fruit yield.

Bardehji et al. [6] studied the effect of different levels of irrigation and plastic mulch on yield and yield components of medicinal Pumpkin (Cucurbita pepo var. styriaca) in Mashhad. Their results showed that reduction in fruit yield under water stress conditions can be related to a reduction in flower production in plant. Mulch had also significant effect $(p<0.01)$ on total dry weight, leaf area index, fruit yield, seed yield, harvest index and also on 1000-seed weight $(p<0.05)$. Use of mulch increased fruit and seed yield and harvest index by $38.4 \%, 38.4 \%$ and $30.6 \%$ compared to the lack of mulch, respectively, through reduced soil evaporation and increases available water of plant. Irrigation $\times$ mulch affected significantly $(p<0.01)$ on total dry weight, leaf area index, harvest index fruit and seed yield and seed weight per plant. Plant yield reduction under drought stress could be attributed to decrease in plant photosynthesis, leaves aging and decrease in gas exchange due to stomatal closure. In general, irrigation of $75 \%$ of the plant's water requirement and the use of plastic mulch are the best condition for planting medicinal pumpkin because it greatly saves water consumption and also had the highest rate of production. The results of this study indicated that irrigation based on plant need can play an important role in increasing yield and yield components of pumpkin plant in drought conditions Also, the plastic mulch by preventing water loss increases the amount of water available to the plant and reduces the effect of stress and improves plant yield.

According to some theories [11], leaf structure enables two opposing processes, namely, to minimize water losses to prevent cell adhesion and at the same time to achieve more balanced access to atmospheric carbon dioxide. If the potential for losses of large quantities of water through transpiration were not present, rainfall is not only source (irrigation, capillary rise, etc.). However, if a viable solution is found to reduce this amount of transpiration (more than $95 \%)$, the water requirement, especially in arid regions, will be greatly reduced. In this way, Extending irrigation interval it could be reduced evaporation from unshaded soil [25] and partially reducing the water shortage yield. But since we are facing a shortage of water resources in our country, one of the solutions to these problems is to conduct applied research in this area. Therefore, in this study, the effect of deficit irrigation and kaolin clay on yield and yield components of pumpkin was investigated.

\section{Materials and methods}

This experiment was conducted base of complete randomized block design to determine the effect of kaolin clay foliar application and deficit irrigation on (bio)-chemical property of pumpkin in a field located in Siahbaz village of Khoy, Iran. It is located at $38^{\circ} 35^{\prime}$ North latitude and $44^{\circ} 52^{\prime}$ East longitude and is $1187 \mathrm{~m}$ above sea level. According to meteorological statistics, the region is hot and semiarid climate with 150 days of dry weather. According to data obtained from weather station situated in vicinity of experimental site, the average annual temperature is $11.5^{\circ} \mathrm{C}$. The minimum and maximum 50-year long-term temperatures were $17^{\circ} \mathrm{C}$ and $35^{\circ} \mathrm{C}$, respectively. The average annual rainfall is $296 \mathrm{~mm}$. The soil characteristics of the field are described in Table 1. Based on soil test results (Table 1), $250 \mathrm{~kg}$ urea fertilizer, $100 \mathrm{~kg}$ triple superphosphate fertilizer and $75 \mathrm{~kg}$ potassium sulfate were recommended to improve soil fertility. This experimental was performed with irrigation at four levels (complete irrigation, deficit irrigation from the shoot stage, deficit irrigation from flowering stage and deficit irrigation from seed filling stage) and three levels of kaolin foliar application (control, $3 \%$ kaolin and $6 \%$ kaolin) with 12 treatments, and three 
Table 1 Physical and chemical properties of the soil used in the experiment

\begin{tabular}{|c|c|c|c|c|c|c|c|c|}
\hline Texture & $\mathrm{pH}$ & $\mathrm{EC}\left(\mathrm{mmhos} \mathrm{cm}^{-1}\right)$ & $P\left(\mathrm{mg} \mathrm{kg}^{-1}\right)$ & $K\left(\mathrm{mg} \mathrm{kg}^{-1}\right)$ & Total $N\left(\mathrm{mg} \mathrm{kg}^{-1}\right)$ & Organic carbon \% & Saturation percentage $\%$ & Lime \% \\
\hline Loam Silt & 7.31 & 1 & 9.11 & 335 & 0.08 & 0.79 & 34.46 & 15.2 \\
\hline
\end{tabular}

repetition was considered. This was a two-year experiment done in 2018-2019. Preparation of soil was carried out in early May 2018. When preparing the soil, all phosphate and potassium fertilizers along with half the urea fertilizer were used as recommended. Half of the rest of the urea fertilizer was spread on the shoot. There were created levels and ridges $30 \mathrm{~cm}$ deep and $2 \mathrm{~m}$ wide. Experimental plot size was $3 \times 4 \mathrm{~m}$ with $1 \mathrm{~m}$ distance between each plot and 10 number of plots. The area of the plots was determined busingrope, and a distance of $3 \mathrm{~m}$ between the plots was considered to prevent water from moving to the adjacent plots. The length of each row was $3 \mathrm{~m}$ and plant spacing was $30 \mathrm{~cm}$ with a density of 33,333 plants in hectare. The planting was done in a hierarchical manner. For this purpose, after grounding, 2-3 disinfected seeds had been soaked in the hot water of the ridges $24 \mathrm{~h}$ earlier. After digging pits at a depth of $5 \mathrm{~cm}$ seeds were planted on May 15, 2019 and covered with soft soil. After germination and plant establishment, thinning of the field was carried out and a strong and healthy plant was maintained, and the other plants were removed. In this study, pumpkin seeds of Hamadani cultivar were used. Weed control was done mechanically by hand. To combat pests, especially aphids, spraying was performed in two stages using by metasystox $\left(1 \mathrm{I} \mathrm{ha}{ }^{-1}\right.$.) There was no specific disease on the farm. Subsequent irrigation was performed based on the type of treatment for each plot the control treatment is treatment with fill (complete) irrigation. Cut irrigation treatment at stem stage, deficit irrigation at flowering stage and cut irrigation at seed filling was performed, and after these stages the plots were stopped until complete maturity. The used kaolin clay powder was made and used by Kimia Sabzavar Company. After a 2-week acclimation period, the plants were split into well-irrigated and water-stressed. The well-irrigated plants were watered up to $100 \%$ of their daily requirements for total evapotranspiration (ET) over the length of the study. Water stress treatment consisted of reducing irrigation by $25 \%$ of ET every 15 days. The ET was determined gravimetrically (weight of pots with plants). Three foliar applications of kaolin were performed with a water pump and mixer on the plant. Deficit irrigation was done at stem treatment with no kaolin spraying, with $3 \%$ kaolin spraying and $6 \%$ kaolin spraying and then the same combination with deficit irrigation at flowering and seed filling. Irrigation intervals were every 12 days. Spraying was done so that the shoot, stem and leaf surfaces of the plant were completely covered. Kaolin solutions were used in each plot in the afternoon. After 50 days from planting, at the end of the growing cycle (from planting to harvest) season and after the bushes were thoroughly mature, experimental plots were sampled to evaluate the desired traits, taking into account the effects of margins and selecting five plants per treatment for sampling. Traits including number of leaves, number of fruits per plant, number of seeds per fruit, fruit yield, 1000 grain weight, biological yield, grain yield, harvest index, oil percentage, protein percentage, protein and oil yield were measured. Oil and protein content of Cucurbita pepo seed powder was determined by the method of [23]. Dried pumpkin seed samples were ground using a kitchen grinder (Oster, model 869-50R, Lakewood, CA, USA). Extraction of lipid fraction of the pumpkin seeds was performed using petroleum ether as a solvent in a Soxhlet extractor, according to AOAC procedure [23]. The extract was dried over $\mathrm{Na}_{2} \mathrm{SO}_{4}$, and then, the solvent was evaporated under reduced pressure using a rotary evaporator (Büchi Rotavapor B-480, Essen, Germany) at $40{ }^{\circ} \mathrm{C}$. Finally, the residue was weighed and dissolved in hexane. The recovered oil was stored at 4 - $C$ until use. Fractionation of the proteins of Cucurbita pepo seeds revealed considerable differences in solubility of the total salt-soluble protein fraction. The major component had crystalline form and solubility at $40 \%$ of (NH4) 2504 saturation, and the minor component had solubility maximum at $60 \%$ saturation [23].

\subsection{Statistical analysis of data}

SPSS software was used for statistical analysis and analysis of variance. Also, Duncan's test was used at $5 \%$ level to compare the means.

\section{Results and discussion}

The results of analysis of variance (Table 2) showed that deficit irrigation treatment at different growth stages had significant effect on leaf number at $1 \%$ probability level, but application of kaolin and interaction of deficit irrigation and kaolin on number of leaves per plant was not significant (Table 2). The results showed that the number of leaves affected by deficit irrigation and the highest number of leaves were observed in control treatment (34.68) and the lowest number of leaves belonged to deficit irrigation treatment at stem stage (17.58) (Fig. 1). Stress at the 
Table 2 Analysis of variance of leaf number, number of fruits, number of seeds per fruit and fruit yield of pumpkin seeds

\begin{tabular}{lcclll}
\hline (S. O. V) & $d f$ & \multicolumn{2}{l}{ Mean of squares } & \\
\cline { 2 - 6 } & & $\begin{array}{l}\text { Leaf number } \\
\text { per plant }\end{array}$ & $\begin{array}{l}\text { Number of } \\
\text { fruits per plant }\end{array}$ & $\begin{array}{l}\text { Number of } \\
\text { seeds per fruit }\end{array}$ & Yield of fruit $\left(\mathrm{kg} \mathrm{ha}^{-1}\right)$ \\
\hline Repeat & 2 & 83.29 & 0.25 & $12,531.18$ & $49,346,945$ \\
Cut irrigation & 3 & $448.61^{* *}$ & $2.76^{* *}$ & $10,549.18^{* *}$ & $1,158,071,229^{* *}$ \\
Error $(A)$ & 6 & 59.10 & 0.13 & 495.1 & $26,829,269$ \\
Kaolin & 2 & $25.07 \mathrm{~ns}$ & $0.24 \mathrm{~ns}$ & $16,673.57^{* *}$ & $157,940,343^{* *}$ \\
Cut irrigation $\times$ kaolin & 6 & $17.98 \mathrm{~ns}$ & $0.22 \mathrm{~ns}$ & $262.49 \mathrm{~ns}$ & $1307729 \mathrm{~ns}$ \\
Error $(B)$ & 16 & 78.52 & 0.26 & 1427.42 & $1,946,119$ \\
CV \% & - & 18.99 & 8.42 & 13.8 & 10.24 \\
\hline
\end{tabular}

$\mathrm{ns}^{*}$ and ${ }^{* *}$ : Nonsignificant and significant at the 5 and $1 \%$ levels of probability, respectively

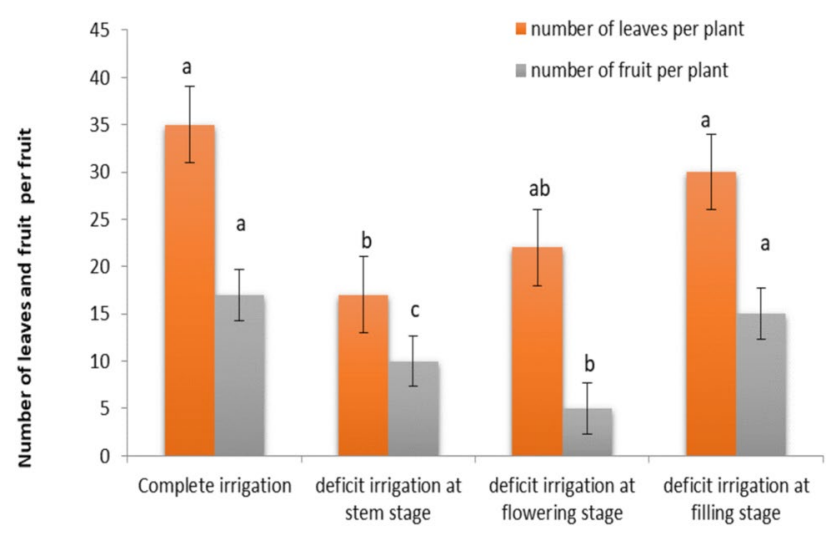

Fig. 1 Mean of effect of deficit irrigation on number of leaves and fruit per plant

stem stage had the greatest negative effect on the number of leaves per plant. The stress at grain filling stage was in the same statistical group. Results showed that deficit irrigation at different growth stages had significant effect on the number of fruits per plant at $1 \%$ probability level (Table 2). In this experiment, results showed that complete irrigation and deficit irrigation after seed filling were significantly better than other irrigation treatments, and deficit irrigation at the stem stage significantly reduced the number of fruits per plant (40\%) (Fig. 1). The effect of deficit irrigation on number of grains per fruit was significant at $1 \%$ probability level (Table 2). Comparison of means showed that the number of grains per fruit decreased from 463.7 grains (complete irrigation) to 261 grains per fruit at severe water deficit level (deficit irrigation at stem stage) (Fig. 2). According to (Fig. 2), it was observed that kaolin 3\% at complete irrigation and deficit irrigation at filling stage had the most effect on grain under stress conditions and the highest number of seeds in fruit. There was no statistically significant difference between 3 and $6 \%$ kaolin. The lowest number of seeds per fruit was related to deficit irrigation at stem stage. The highest fruit yield was in the

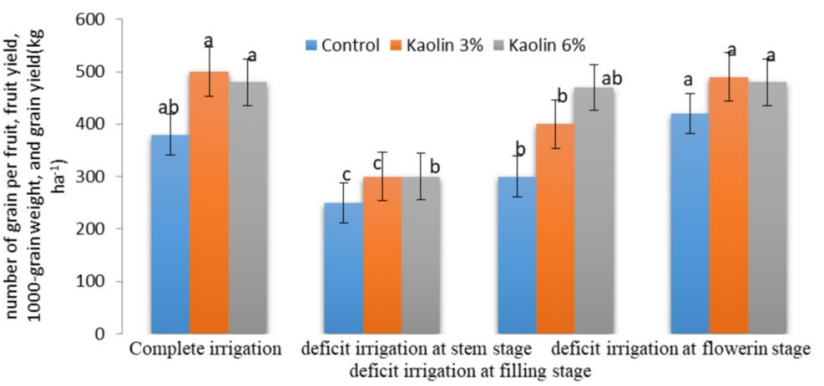

Fig. 2 Mean the effect of deficit irrigation and Kaolin on number of grain per fruit, fruit yield and grain yield

complete irrigation and deficit irrigation at filling stage and the lowest fruit yield was in deficit irrigation at the stem stage $\left(13.4 \mathrm{~kg} \mathrm{ha}^{-1}\right)$, and difference between 3 and $6 \%$ kaolin was not significant (Fig. 2). Also, according to the results the highest fruit yield $\left(23.84 \mathrm{~kg} \mathrm{ha}^{-1}\right)$ was obtained from $3 \%$ kaolin at complete irrigation and the lowest fruit yield was obtained with $6 \%$ kaolin treatment at deficit irrigation at filling stage. The effect of deficit irrigation on 1000 -grain weight was significant at $5 \%$ probability level (Table 3). Comparison of means showed that the 1000grain weight decreased at complete irrigation (204 g) than deficit irrigation at stem elongation (197.8 g) (Fig. 2). 1000-grain weight were affected by kaolin application at $1 \%$ probability level (Table 3 ). According to Fig. 2 , it can be seen that the highest 1000 grain weight $(300 \mathrm{~g})$ was related to $3 \%$ kaolin at complete irrigation and deficit irrigation at filling stage and the lowest 1000 grain weight (200.27 g) was related to complete irrigation at deficit irrigation at stem stage (Fig. 2). The effect of deficit irrigation on grain yield was significant at $1 \%$ probability level (Table 3). Grain yield decreased in complete irrigation $\left(807.2 \mathrm{~kg} \mathrm{ha}^{-1}\right)$ and deficit irrigation at stem stage $\left(292.5 \mathrm{~kg} \mathrm{ha}^{-1}\right)$. As a result of deficit irrigation on grain yield at flowering stage (66.2\%), flowering till the end of growing season (18.3\%) decreased, respectively. It seems that deficit irrigation at grain filling stage due to approaching the end of the 
Table 3 Analysis of variance of 1000-grain weight, grain yield, biological yield and harvest index of pumpkin seeds

\begin{tabular}{lccccc}
\hline S. O. V) & $d f$ & \multicolumn{2}{l}{ Mean of squares } & & \\
\cline { 3 - 6 } & & $\begin{array}{l}\text { Leaf 1000-grain } \\
\text { weight }(\mathrm{g})\end{array}$ & Grain yield $\left(\mathrm{kg} \mathrm{ha}^{-1}\right)$ & Biological yield $\left(\mathrm{kg} \mathrm{ha}^{-1}\right)$ & Harvest index $(\%)$ \\
\hline Repeat & 2 & 99.88 & $10,284.77$ & $264,386.6$ & 1.9 \\
Cut irrigation & 3 & $311.79^{*}$ & $320,353.27^{* *}$ & $3,264,797.8^{* *}$ & $120.2^{* *}$ \\
Error $(A)$ & 6 & 42.71 & 2057.26 & $78,958.9$ & 16.1 \\
Kaolin & 2 & $1323.85^{* *}$ & $58,969.58^{* *}$ & $1,303,985.5^{* *}$ & $232.9^{* *}$ \\
Cut irrigation $\times$ kaolin & 6 & $69.320 \mathrm{~ns}$ & $8121.76 \mathrm{~ns}$ & $192,708.2 \mathrm{~ns}$ & $29.7 \mathrm{~ns}$ \\
Error $(B)$ & 16 & 96.17 & 4851.47 & $136,622.1$ & 24 \\
CV \% & - & 13.96 & 19.5 & 11.4 & 18.3 \\
\hline
\end{tabular}

$\mathrm{ns}^{*}{ }^{*}$ and ${ }^{* *}$ : Nonsignificant and significant at the 5 and $1 \%$ levels of probability, respectively

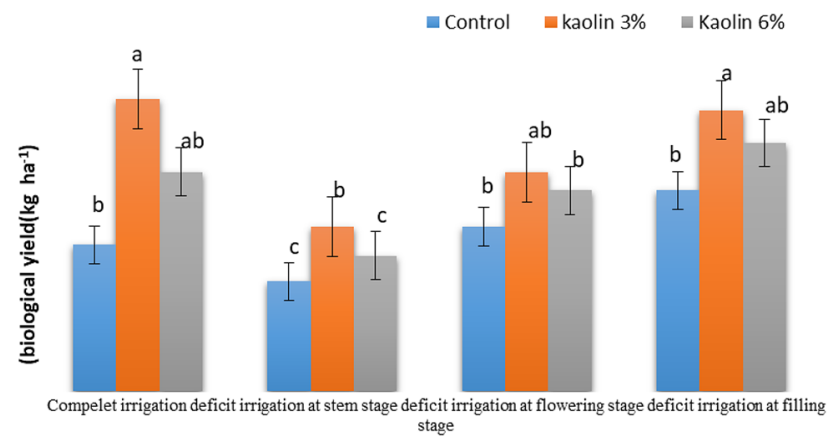

Fig. 3 Mean the effect of deficit irrigation and Kaolin on biological yield

growing season and the presence of sufficient water in the soil profile as well as the presence of extended root prevented a significant decrease in yield (Fig. 2). According to the results of analysis of variance, the grain yield of pumpkin at $1 \%$ probability level was significantly affected by kaolin anti-transpiration solution (Table 3). According to Fig. 6 , the highest grain yield $\left(793.7 \mathrm{~kg} \mathrm{ha}^{-1}\right)$ was obtained with $3 \%$ kaolin at complete irrigation and the lowest grain yield ( $315.5 \mathrm{~kg} \mathrm{ha}^{-1}$ ) with complete irrigation at deficit irrigation at stem stage. Results showed that deficit irrigation had significant effect on biological yield at $1 \%$ probability level (Table 3). The highest biological yield ( $800 \mathrm{~kg} \mathrm{ha}^{-1}$ ) was obtained with $3 \%$ kaolin at complete irrigation and deficit irrigation at filling stage, and the lowest biological yield $\left(274 \mathrm{~kg} \mathrm{ha}^{-1}\right.$ ) was obtained with control treatment at deficit irrigation at stem stage (Fig. 3). Results indicated that effect of deficit irrigation and kaolin on harvest index had significant at $1 \%$ probability level (Table 3 ). The highest harvest index (16.2\%) was observed with 3\% kaolin at complete irrigation and deficit irrigation at filling stage. Deficit irrigation at stem elongation stage had the lowest harvest index (12.13\%) (Fig. 4). The control treatment (distilled water spray) with $16.11 \%$ had the highest harvest

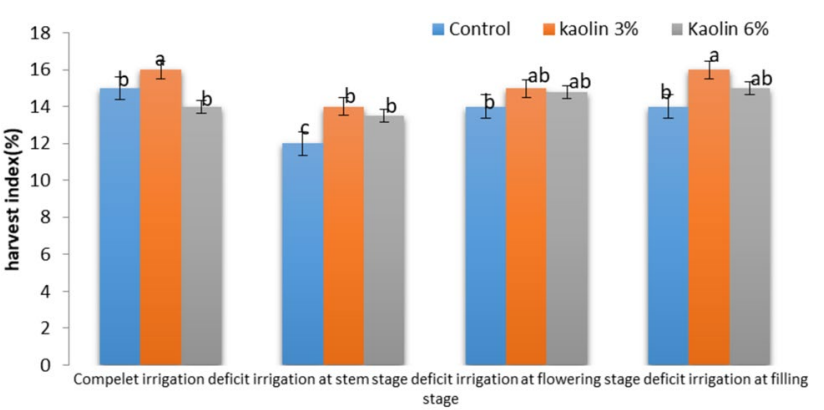

Fig. 4 Mean the effect of deficit irrigation and Kaolin on harvest index

index, and the $6 \%$ kaolin was in the statistical group b (Fig. 4). The effect of deficit irrigation on the percentage of grain oil was significant at $1 \%$ probability level (Table 4). The percentage of grain oil decreased from complete irrigation and deficit irrigation at filling stage (46.25\%) to deficit irrigation at stem to harvest $37.9 \%$ (Fig. 5). In this experiment, the highest grain oil content was observed with $3 \%$ kaolin at complete irrigation and deficit irrigation at filling stage and the lowest grain oil content was observed with control treatment at deficit irrigation at stem stage (Fig. 6). According to the results, the effect of deficit irrigation on grain oil yield was significant at $1 \%$ probability level (Table 4). Comparison of means showed that grain oil yield increased in complete irrigation (353.34 $\mathrm{kg} \mathrm{ha}^{-1}$ ) and decreased in deficit irrigation at grain filling stage and deficit irrigation at stem elongation to $\left(100.32 \mathrm{~kg} \mathrm{ha}^{-1}\right)$. Severe drought stress (deficit irrigation at the stem stage) decreased by $72 \%$ compared to the complete irrigation treatment (Fig. 6). The effect of kaolin on grain oil yield was significant at 5\% probability level (Table 4). The highest grain oil yield was obtained with $3 \%$ kaolin treatment at complete irrigation and deficit irrigation at filling stage, and the lowest grain oil yield was obtained in complete irrigation treatment (Fig. 6). The results showed that the 
Table 4 Analysis of variance of Percentage of oil, percentage of protein and oil yield and protein yield of pumpkin seeds

\begin{tabular}{llcccc}
\hline S. O. V) & $d f$ & \multicolumn{2}{l}{ Mean of squares } \\
\cline { 2 - 6 } & & $\begin{array}{l}\text { Percentage of } \\
\text { oil (\%) }\end{array}$ & $\begin{array}{l}\text { Percentage of } \\
\text { protein (\%) }\end{array}$ & Oil yield $\left(\mathrm{kg} \mathrm{ha}^{-1}\right)$ & $\begin{array}{l}\text { Protein } \\
\text { yield } \\
\left(\mathrm{kg} \mathrm{ha}^{-1}\right)\end{array}$ \\
\hline Repeat & & & & 0.30 & 427.1 \\
Cut irrigation & 2 & 116.25 & 5019.52 & $1.76^{*}$ & $1518^{* *}$ \\
Error $(A)$ & 3 & $280.58^{* *}$ & $79,234.36^{* *}$ & 0.18 & 434.8 \\
Kaolin & 6 & 2.25 & 582.31 & $6110.9^{* *}$ \\
Cut irrigation $\times$ kaolin & 6 & $86.47^{* *}$ & $6465.27^{*}$ & $3.38^{* *}$ & $1295.5 \mathrm{~ns}$ \\
Error $(B)$ & 16 & 22.23 & 2015.16 & 0.15 & 1156.5 \\
CV \% & - & 11.01 & 18.4 & 6.4 & 20.4 \\
\hline
\end{tabular}

$\mathrm{ns}^{*}{ }^{*}$ and ${ }^{* *}$ : Nonsignificant and significant at the 5 and $1 \%$ levels of probability, respectively

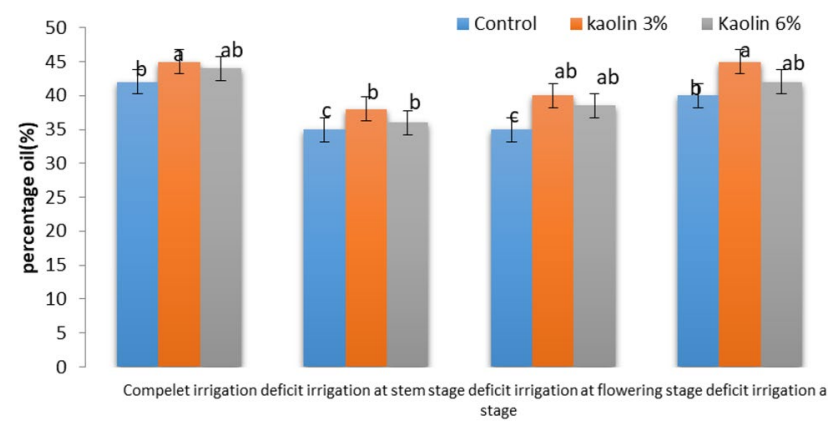

Fig. 5 Mean of the effect of deficit irrigation and kaolin on percentage oil

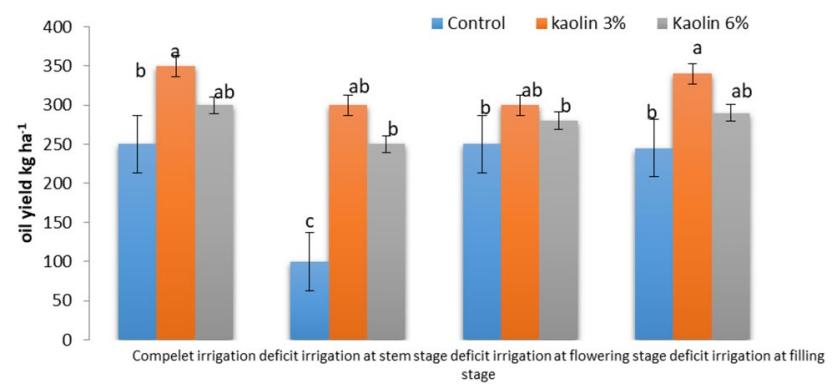

Fig. 6 Mean of the effect of deficit irrigation and kaolin on oil yield

percentage of protein in different treatments had a significant difference at $5 \%$ probability level (Table 4$)$. The highest percentage of protein $(12.99 \%)$ was observed with 3\% kaolin in deficit irrigation at grain filling stage. Control treatment at deficit irrigation at stem stage with protein percentage (11.58\%) had the lowest protein content (Fig. 7). Analysis of variance showed that irrigation treatments at $5 \%$ probability level and $1 \%$ probability of kaolin had a significant effect on protein yield (Table 4). The highest protein yield was obtained $98.53 \mathrm{~kg} \mathrm{ha}^{-1}$ with $3 \%$ kaolin at complete irrigation and deficit irrigation at

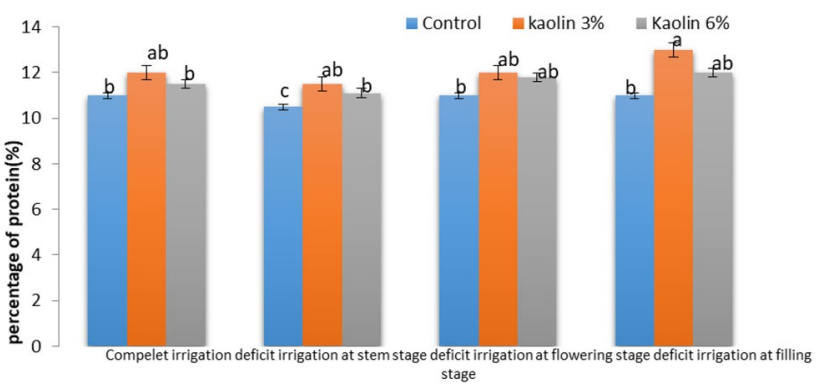

Fig. 7 Mean of the effect of deficit irrigation and kaolin on percentage of protein

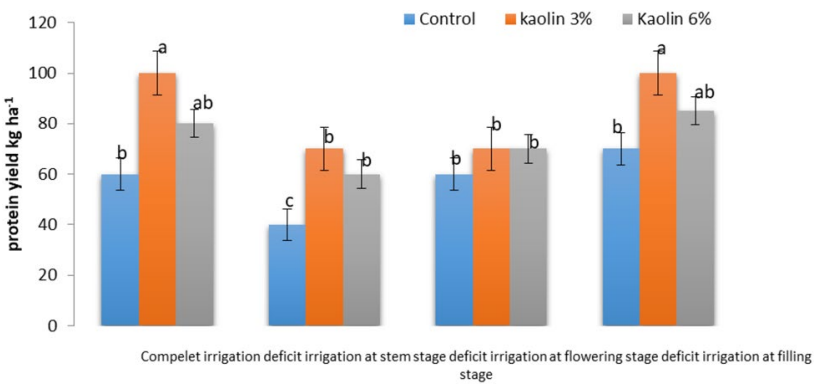

Fig. 8 Mean of the effect of deficit irrigation and kaolin on protein yield

filling stage. Pre-flowering drought stress had the highest effect on protein yield reduction due to significant decrease in grain yield. The flowering stage was ranked b group in statistics (Fig. 8). Three percent kaolin had the highest protein yield $\left(98.53 \mathrm{~kg} \mathrm{ha}^{-1}\right)$. Six percent kaolin at complete irrigation and deficit irrigation at filling stage were in the second group with mean of $76.35 \mathrm{~kg} \mathrm{ha}^{-1}$, and control treatment at deficit irrigation at stem stage with $41.55 \mathrm{~kg} \mathrm{ha}^{-1}$ had the lowest protein yield (Fig. 8).

Drought stress decreases leaf area, loss of freshness and decrease in leaf number of plants. As a result, all of these factors contribute to reduction of dry matter 
and yield under drought conditions, which is in accordance with the results obtained in this experiment. In this experiment, the number of leaves in plants that were suitable under water conditions was higher than under stress conditions. Severe water scarcity has been reported to reduce leaf area development in several plants [9]. The decrease in leaf number under severe stress conditions may be due to a decrease in leaf formation and increase in lower leaf loss. Decreased leaf growth under osmotic stress reduces cell division rate and cell development due to loss of turgor pressure and leaf loss due to production of ethylene and $A B A$ under drought stress conditions [36]. One of the strategies of the plant is to reduce leaf area and number of leaves at the time of stress. Leaf as a photosynthetic unit in the plant has a special role; genotypes with higher leaves have high photosynthetic potential under stress conditions, but this is in contrast with more transpiration in these conditions. Evidence suggests that there is a weak relationship between aerial characteristics in reducing water transpiration and increasing yield [20]. There must be a balance between reduced transpiration and the critical leaf area for photosynthesis. Changing leaf area is an important process whereby crops under stress maintain their control over water use. Results of several experiments indicate that vegetative growth, especially leaves, was affected by water deficit stress. Decreased water availability, reduced water and nutrient uptake, reduced photosynthesis ultimately reduced the number and size of leaves. Under drought stress, dry matter depletion can be due to cell swelling pressure due to lower leaf area and to photosynthesis due to biochemical constraints such as reduced photosynthetic pigments [27].

Youssef et al. [39] reported on the applications of different water deficiency levels $(100 \%, 80 \%$ and $60 \%$ of F.C., i.e., field capacity) and ascorbic acid (AsA) spraying foliar application with different concentrations $(0,50$ and $100 \mathrm{ppm}$ ) as antioxidant on growth parameters and yield as well as photosynthetic pigments content of summer squash plants (Cucurbita pepo L.cv. Eskandrani). Their results indicated that decreasing water levels caused a significant reduction in the all tested growth and yield parameters, i.e., canopy weight, root weight, number of leaves, leaves fresh weight and leaf area as well as photosynthetic pigments content (total chl. and carotenoids), total yield, fruit weight and length. While increasing ascorbic acid spraying foliar application levels as antioxidant significantly increased the aforementioned parameters in the two seasons as compared with control. On the other hand, decreasing water levels caused a significant increase in leaf proline content, leaf cell sap osmotic pressure, dry matter \% and fruit TSS in the two growing seasons as compared with control. That was consistent with our results.
The results of Al-Omran et al. [3] showed that the number of fruits per plant decreased due to water deficit stress, which is in accordance with the results of this study. Taheri [34] showed that drought stress decreases the number of fruits per plant, as the final number of seeds per fruit and drought stress in deficit irrigation at flowering stages had the greatest effect on decreasing fertilization and fertility of flowers, and fewer seeds are produced in fruits that was consistent with our results. The decrease in number of seeds per fruit due to drought stress can be due to loss of pollen, oocyte or embryo, as well as disruption of current photosynthesis and transfer of storage materials to seeds, which reduces the number of seeds per fruit [2]. There was no significant difference in number of seeds during water stress after anthesis; the final number of seeds was determined at anthesis, and insufficient photosynthetic material available for growth of all embryonic cells had a negative effect on the number of seeds [38] that was consistent with our results. In a study [12] that investigated the effects of irrigation regimes and row spacing on the yield, yield components, and quality of pumpkin seeds, the number of seeds per fruit decreased with increasing stress level, which is in agreement with the results of this experiment. The decrease in number of seeds per fruit in control and stressed plants was due to interruption of irrigation and water deficit in plants while in sprayed plants with anti-transpiration, reduced transpiration and increased plant water potential partly prevented seed formation. This results with increasing of number of grain per fruit in plants treated with stress transpiration compared to control and stressed plants [31] that was consistent with our results. An increase in the number of grains per wheat cluster was reported by $6 \%$ as a result of spraying with kaolin. Application of kaolin in stem and flowering stages of wheat increased the relative amount of leaf water, which in turn reduced the damaging effects of seed loss and consequently reduced seed loss under water restriction conditions. Increasing fruit yield with the use of kaolin can be attributed to increased grain length and width, fruit length and diameter, increased number of seeds per fruit and 1000-grain weight gain, which can be justified by recent improved traits. As can be seen from the our results, early deficit irrigation (stem initiation) by reducing leaf number and photosynthetic area and decreasing number of fruits per plant had the greatest effect on decreasing fruit yield. It seems that the decrease in fruit yield under drought stress is due to the decrease in leaf area index, chlorophyll concentration and net photosynthetic rate of the plant before and during the formation of reproductive organs and fruits [2]. In a study by Al-Omran et al. [3], drought stress caused a decrease in fruit yield of pumpkin. Weight gain of apples in the treatment with kaolin antiperspirant produced higher yield under full irrigation 
conditions than in the low irrigation condition [14]. With the onset of the reproductive phase in different plants, the major destination for photosynthetic material is the seed. Any environmental factor that is not at its optimum level during plant growth can result in reduced production, storage and ultimately reduction in the allocation of photosynthetic materials to the seeds. Water deficit stress during grain filling decreases grain yield by reducing photosynthesis [32]. Therefore, the destination need for grain filling was more pronounced than in non-stress conditions through remobilization of stored photosynthetic materials [25].

Tambussi and Bort [35] reported that the coatings of the surface layer of leaves and the compounds that close the stomata increase the resistance of the leaf to water loss and enhance the grain yield by enhancing plant moisture status and carbohydrate assimilation. Kaolin's efficiency was more efficient because of its ability to reduce leaf temperature, transpiration rate, expansion of plant water and preservation of potato dry matter that was consistent with our results. Abd El-Aal et al. [1] reported that application with anti-transpiration materials resulted in higher growth and yield than control plants (non-transpiration materials). Drought stress decreases photosynthesis due to decreased carbon dioxide uptake and also due to decreased enzyme activity. In clover under stress conditions, total and initial activity of the rubisco enzyme decreased, but the amount of this protein did not change much. The transport of photosynthetic materials was affected by drought stress, which leaves saturated with these materials and limits photosynthesis. Drought stress, while reducing leaf area, accelerates its aging as well, thereby reducing the rate of production much more than it is due to the effects of reduced photosynthetic damage [20] that was consistent with our results. Application of anti-transpiration materials under irrigation limitation conditions has shown that application of anti-transpiration materials with preservation of plant moisture has partially offset the effects of moisture deficiency. Many researchers because of the use of antiperspirants have reported increased carbon assimilation and photosynthesis. This, as mentioned, is due to the relative leaf water content, increasing the activity of the rubisco enzyme in the photosynthesis process in a way that promotes vegetative growth [20] that was consistent with our results. As the water consumption decreases, the harvest index decreases because of the water scarcity on reproductive processes is more than vegetative. The final weight of grain in fruit, which is an important component of yield, was influenced by two components of grain filling rate and duration. These two factors have been used to analyze grain growth and how plant and environmental factors affect it [4]; it is in accordance with my finding. Kazempour Azar and Tajbakhsh [21] reported the increase in harvest index because of application of anti-transpiration materials on maize. With the application of antiperspirants, the harvest index is increased, which may be due to maintaining relative plant moisture and reducing transpiration water loss and thus improving metabolic, enzymatic and protein synthesis activity under drought stress. The decrease in oil content due to drought stress can be due to disturbance in grain filling; it is in accordance with my finding. In a Taheri study [34] reported a 56\% decrease in seed oil content under water deficit stress in different pumpkin seed. The decrease in the abundance of polyribosomes is associated with a decrease in protein synthesis. The number of polyribosomes decreases under dehydration conditions in maize indicates that increasing water stress causes a decrease in the level of polyribosomes and plant species that have survived under these conditions have greater capacity and ability to produce polyribosomes. Their textures have shown that the amount of total protein decreases and the amount of free amino acids increases [20]; it is in accordance with my finding. Under water deficit conditions, a significant increase in proline concentration, along with a significant decrease in soybean leaf proteins can be attributed to both protein degradation and reduced synthesis. It should be noted that the decrease in protein concentration under drought stress, which is associated with a decrease in rubisco enzymes and photosynthetic deficiency, is due to increased activity of protein degrading enzymes [20]. This result is in agreement with the results of this study that had reduced protein intake after deficit irrigation without spraying by kaolin of pumpkin while improving the moisture status of treated plants compared to control plants (without anti-transpiration material) and under water deficit condition increased cell division, nitrogen metabolism and enzymatic activity [21] and ultimately increased protein content. Abd El-Aal et al. [1] reported an increase in protein content in eggplant in 10- and 21-day irrigation conditions using antiperspirants; it is in accordance with my finding. Due to the increase in grain yield and protein percentage under the influence of $3 \%$ kaolin application, the increase in protein yield can be justified. Treatment with 3\% kaolin produced the highest grain yield compared to the control, and the highest protein yield was obtained for this treatment.

\section{Conclusion}

Based on the results, deficit irrigation at seed filling stage was superior to other treatments, so that there was no significant difference in all traits with complete irrigation treatment. Based on the fact that deficit irrigation at filling stage and complete irrigation were in the same group, it can be concluded that kaolin 3\% had more effect on 
grain yield. The highest percentage of protein and protein yield belonged to kaolin 3\% at complete irrigation and deficit irrigation at grain filling stage and the lowest of all traits was related to control treatment at deficit irrigation at stem to harvest stage. The highest number of grains per fruit, fruit yield, 1000-grain weight, grain yield, protein percentage, protein yield and biological yield were obtained in 3\% kaolin at complete irrigation and deficit irrigation at grain filling stage. In general, it can be said that the kaolin antiperspirant used in this experiment under irrigation limitation conditions could partially offset the water-deficit yield due to water deficit in control plants (without the use of antiperspirants). Due to lack of water, they had less yield than treated plants.

\section{Declarations}

Conflict of interest The authors declare that they have no conflict of interest.

Open Access This article is licensed under a Creative Commons Attribution 4.0 International License, which permits use, sharing, adaptation, distribution and reproduction in any medium or format, as long as you give appropriate credit to the original author(s) and the source, provide a link to the Creative Commons licence, and indicate if changes were made. The images or other third party material in this article are included in the article's Creative Commons licence, unless indicated otherwise in a credit line to the material. If material is not included in the article's Creative Commons licence and your intended use is not permitted by statutory regulation or exceeds the permitted use, you will need to obtain permission directly from the copyright holder. To view a copy of this licence, visit http://creativecommons. org/licenses/by/4.0/.

\section{References}

1. Abd El-Aal FS, Abdel Mouty MM, Ali AH (2008) Combined effect of irrigation intervals and foliar application of some anti-transpiration on plant growth, fruit yield and its physical and chemical properties. Res J Agric Biol Sci 4:416-423

2. Agayi A, Ehsanzadeh P (2013) Effect of irrigation and nitrogen regime on yield and some physiological parameters of paper pumpkin medicinal plant. Iranian Hort Sci 2:19-28

3. Al-Omran AM, Sheta AS, Falatah AM, Al-Harbi AR (2005) Effect of drip irrigation on squash (Cucurbita pepo) yield and water-use efficiency in sandy calcareous soils amended with clay deposits. Agric Water Management 73:43-55

4. Ahmadi A, Ehsanzadeh P, Jabari F (2011) Introduction to plant physiology. University of Tehran Press Institute. 653 pages

5. Aroei H, Kashi A, Omidbeigi R (2010) Evaluation of different levels of nitrogen on some pumpkin traits. J Res Constr 9:48

6. Bardehji S, Bannayan M, Asadi GH (2019) studied the effect of different levels of irrigation and plastic mulch on yield and yield components of medicinal Pumpkin (Cucurbita pepo var. styriaca) in Mashhad. Iran J Field Crops Res 17(2):265-273

7. Bernath J (2003) Wild and cultivated medicinal plants. Pup. Budapes, Mezo, p 566
8. Denaxa NK, Roussos PA, Damvakaris T, Stournaras V (2012) Comparative effects of exogenous glycine betaine, kaolin clay particles and ambiol on photosynthesis, leaf sclerophylly indexes and heat load of olive cv. Chondrolia Chalkidikis under Drought. Sci Hortic 137:87-94

9. Farouk S, Ramadan-Amany A (2012) Improving growth and yield of growth by foliar application of chitosan under water stress. Egyption J Biol 14:14-26

10. Fumiomi Takeda DM (2005) weed control with hydrophobic and hydrous kaolin clay particle mulches. Hort Sci 40(3):714-719

11. Gerhards $M$, Schlerf $M$, Rascher $U$, Udelhoven $T$, Juszczak $T$, Alberti G, Miglietta F, Inoue Y (2018) Analysis of airborne optical and thermal imagery for detection of water stress symptoms. Remote Sens 10:1-23

12. Ghanbari A, Nadjafi F, Shabahang J (2007) Effects of irrigation regime and row arrangement on yield, yield components and seed quality of pumpkin (Cucurbita pepo L.). Asian J Plant Sci 6:1072-1079

13. Glenn DM, Erez A, Puterka GJ, Gundrum P (2003) Particle films affectcarbon assimilation and yield in 'Empire' apple. J Am Soc Hortic Sci 128:356-362

14. Glenn DM (2009) Particle film mechanisms of actions that reduce the effect of environmental stress in empire apple. J Am Soc Hort Sci 134:314-321

15. Glenn DM, Cooley N, Walker R, Clingeleffer P, Shellie K (2010) Impact of kaolin particle film and water deficit on wine grape water use efficiency and plant water relations. Hort Sci 45:1178-1187

16. Habibi A, Heidari G, Sohrabi Y, Badakhshan H (2014) Effect of different fertilization systems on yield and seed mineral elements of pumpkin. Iran Agric Res 33(2):83-93

17. Hamzei J, Babaei M (2017) Response of morphological traits, yield components and yield of pumpkin (Cucurbita pepo L.) to the integrated management of irrigation interval and nitrogen fertilizer. Electron J Crop Prod 9(4):17-35

18. Ibrahim EA, Selim EM (2010) Effect of irrigation intervals and antitranspirant (kaolin) on summer squash (Cucurbita pepo L.) growth, yield, quality and economics. J Soil Sci Agric Eng 32(12):10333-10345

19. Jifon JL, Syvertsen JP (2003) Kaolin particle film applications can increase photosynthesis and water use efficiency of 'ruby red' grape fruit leaves. J Am Soc Hortic Sci 128:107-112

20. Kafi M, Rostami M (2007) Effect of drought stress on reproductive growth stage on yield, yield components and percentage of three oils of three safflower cultivars under saline irrigation conditions. Iranian Agric Res 5:110-121

21. Kazempour Azar S, Tajbakhsh M (2012) Effect of some antiperspirants on vegetative characteristics, yield and yield components of corn under limited irrigation conditions. Iranian J Agric Sci 2:205-211

22. Khodabandeh N, Jalilian A (2007) Effect of drought stress on germination stages on soybean seed germination and potency. Iranian J Agric Sci 1:11-18

23. Kim A (2012) Assessment report on Cucurbita pepo L., semen. Based on Article $16 \mathrm{~h}$ of Directive 2001/83/EC as amended (traditional use). 20 Novmber 2012

24. Kochaki A, Hosseini M, Nasiri Mahalati M (2002) Relationship between water and soil in crops. Publications University of Mashhad. 56 pages

25. Kochaki Gh A, Sarmadnia M (2010) Crop physiology. Publications University of Mashhad. 400 pages

26. Kumudini S, Hume DJ, Chu G (2002) Genetic improvement in short season soybean (nitrogen accumulation, remobilization and partitioning. Crop Sci 42:141-145 
27. Lawlor DW, Cornic G (2002) Photosynthetic Carbon assimilation and associated metabolism in relation to water deficits in higher plants. Plants Cell Environ 25(2):275-294

28. Moftah AE, Al-Humaid AR (2005) Effects of anti-transpirants on water relations and photosynthetic rate of cultivated tropical plant (Polianthes tuberosa L.). Polish J Ecol 53:165-175

29. Mozaffarian V (2012) Identification of medicinal and aromatic plants of Iran. Contemporary Culture Publications. 762 pages

30. Paksoy M, Aydin C (2004) Some physical properties of edible squash (Cucurbita pepo L.) seeds. J Food Eng 65:225-231

31. Rajinta B, Janawade AD, Palled YB (2007) Effect of Irrigation scheduales, Mulch and Anti transpiration on Growth, yield and economics of wheat. Karanataka J Agric Sci 20(1):6-9

32. Habib A, Biswas $S$, Siddique AH, Manirujjaman Belal Uddin, Hasan M, Meftah Uddin S, Islam M, Hasan M, Rahman M (2015) Nutritional and lipid composition analysis of pumpkin seed (Cucurbita maxima Linn.). J Nutr Food Sci 5(4):1000374-1000377

33. Rosati A, Metcalf SG, Buchner RP, Fulton AE, Lampinen BD (2006) Physiological effects of kaolin applications in well-irrigated and water-stressed walnut and almond trees. Ann Bot 98:267-275

34. Taheri A (2011) Investigation of some photosynthetic and physiological properties of four pumpkin seeds under water deficit stress. Master of Science Degree in Agriculture, Faculty of Agriculture, Isfahan University of Technology. 85 pages

35. Tambussi EA, Bort J (2007) Water use efficacy in C3 cereals under Mediterranean conditions: a review of physiological aspects. Ann Appl Biol 150:307-321

36. Tezara W, Mitchell V, Driscoll S, Lawlor D (2002) Effects of water deficit and its interaction with $\mathrm{CO}_{2}$ supply on the biochemistry and physiology of photosynthesis in sunflower. J Exp Botany 53:1781-1791

37. Wand SJE, Moris S, Brown P, Gracie A (2004) Rural Industries research and development Groporation

38. Westgate ME (2014) Water status and development of maize endosperm and embryo during drought. Crop Sci 34:76-83

39. Youssef AE, Baset MM, El-Shafie AF, Hussein MM (2017) Study the applications of water deficiency levels and ascorbic acid foliar on growth parameters and yield of summer squash plant (Cucurbita pepo L.). Agric Eng Int CIGR J 2018:147-158

Publisher's Note Springer Nature remains neutral with regard to jurisdictional claims in published maps and institutional affiliations. 